\title{
Maakt onbekend ook onbemind?
}

Om ons heen bevinden zich een groot aantal apparaten met daarin een laser, zonder dat we dat door hebben. In de medische wereld is het gebruik van lasers heel gewoon. Bij de tandarts kom je ze bijna niet tegen in de behandelkamer. Is dat te verklaren? In dit artikel ga ik daarop in en vertel over de verschillende dentale lasers die er op de markt zijn. Ook leg ik de werking uit en laat ik een aantal behandelingen en ervaringen zien uit mijn dagelijkse praktijk.

\section{Auteur}

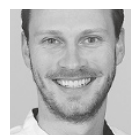

Christiaan Teunis (Nijmegen, 2009) is als tand arts werkzaam bij Kliniek voor Mondgezondheid in Nijmegen. Sinds 2014 gebruikt hij lasers bij zijn tandheelkundige werkzaamheden en geeft hij lezingen op dit gebied.
De oorsprong van de laser gaat een eind terug in de tijd: in 1916 schreef Albert Einstein zijn theorie over lasers (een acroniem voor light amplification by stimulated emission of radiation). Het is een verzamelterm voor een groot aantal verschillende apparaten. In 1960 bouwde Theodore H. Maiman de eerste laser en pas in $1989 \mathrm{kwam}$ pas de eerste dentale laser op de markt. Ik vergelijk het licht van de laser met die van een zaklamp. Je kan er continu mee schijnen: 'continuous wave' genoemd. Je kan je zaklamp feller maken (energie output verhogen) of dempen (energie output lager zetten). Maar vaak knipper je met het licht: korte lichtpulsen oftewel 'pulse mode'. Je varieert dan de belichtingsduur. Dit gebeurt bij de laser en je praat dan over lichtpulsen van een duizendste van een seconde (0,001 sec.). Door de belichtingsduur en de energie output aan te passen kan je heel gedoseerd energie overbrengen zonder oververhitting. Met een boor of elektrotoom is dit veel lastiger. Het licht dat uit de laser komt verschilt per type. De golflengte van de verschillende beschikbare lasers loopt uiteen van blauw licht (445 nm) tot onzichtbaar licht (10.600 nm). Dat licht is net röntgenstraling. Het kan dwars door het weefsel heen gaan (transmissie), gereflecteerd worden (reflectie) of verstrooid worden (scatter). Licht kan ook geabsorbeerd worden en deze eigenschap, absorptie, is hetgeen waar laser gebruik van maakt. Licht van verschillende golflengtes wordt door verschillende chromoforen (het gedeelte van het molecuul dat verantwoordelijk is voor absorptie van licht) geabsorbeerd. Voorbeelden van chromo- foren zijn collageen, keratine, melanine, hemoglobine, water en hydroxyapatiet. Laten die stoffen nu precies in en rond de mond aanwezig zijn. Bij gebruik van de laser worden de weefsels zeer kort belicht (de energie wordt overgebracht) en krijgen vervolgens de kans om af te koelen. Je probeert met zo min mogelijk energie een zo maximaal resultaat te behalen. Bijvoorbeeld bij het verwijderen van tandvlees. Je wil het tandvlees weghalen, zonder het te verbranden of het onderliggende bot te beschadigen. Minder schade leidt tot minder napijn en een snellere genezing. Niet alleen is het opwekken van het licht zelf complex, ook het licht vanuit het apparaat op de gewenste plek krijgen is lastig. Hiervoor worden dure kabels of articulerende armen gebruikt. Via een hoekstuk met daarin een tip komt het licht naar buiten (afbeelding 1). Laserlicht is gevaarlijk voor de ogen. Daarom is bij gebruik een veiligheidsbril voor de behandelaar, patiënt en assistent verplicht (afbeelding 2).

\section{DE PRAKTIJK}

Dentale lasers worden in twee groepen verdeeld. Hieronder volgt een korte beschrijving en hun toepassingsgebieden.

Het eerste type laser is relatief klein (afbeelding 3) en bevat een semiconductor. Dit wordt ook wel een diodelaser genoemd. De semiconductor bevat dan bijvoorbeeld aluminium gallium arsenide en de lasertip hoeft niet gekoeld te worden met water. Het laserlicht wordt geabsorbeerd door melanine (in de huid) en hemoglobine (in het bloed). 
De diodelaser wordt ook wel een 'soft tissue laser' genoemd, omdat harde weefsels zoals tand en bot hiermee niet verwijderd kunnen worden. Eenvoudig gezegd wordt de diodelaser vaak de vervanger van de elektrotoom genoemd. Daar doe je het apparaat echt tekort mee. Het laserlicht van de diodelaser wordt geabsorbeerd door melanine en hemoglobine. Melanine bevindt zich in de huid en hemoglobine in het bloed. Deze lasers worden gebruikt voor het verwijderen van zachte weefsels en om bloed te stoppen (coaguleren). Denk hierbij aan het uitvoeren van een gingivectomie (afbeelding 4-6) of het verwijderen van een fibroom (afbeelding 7-9).

\section{Fotobiomodulatie}

Bij dit type laser treedt er nog een ander effect op. Bij lage energie krijg je fotochemische reacties: cellen reageren op licht. Aangenomen wordt dat de mitochondria (energiefabriekjes van de cel)
$>$ Afb. 1 Hoekstuk van laser lijkt op een regulier hoekstuk.

〉 Afb. 2 Verschillende brillen voor verschillende golflengtes.

$\checkmark$ Afb. 3 Diodelaser Biolase Epic $940 \mathrm{~nm}$ met draadloos voetpedaal.
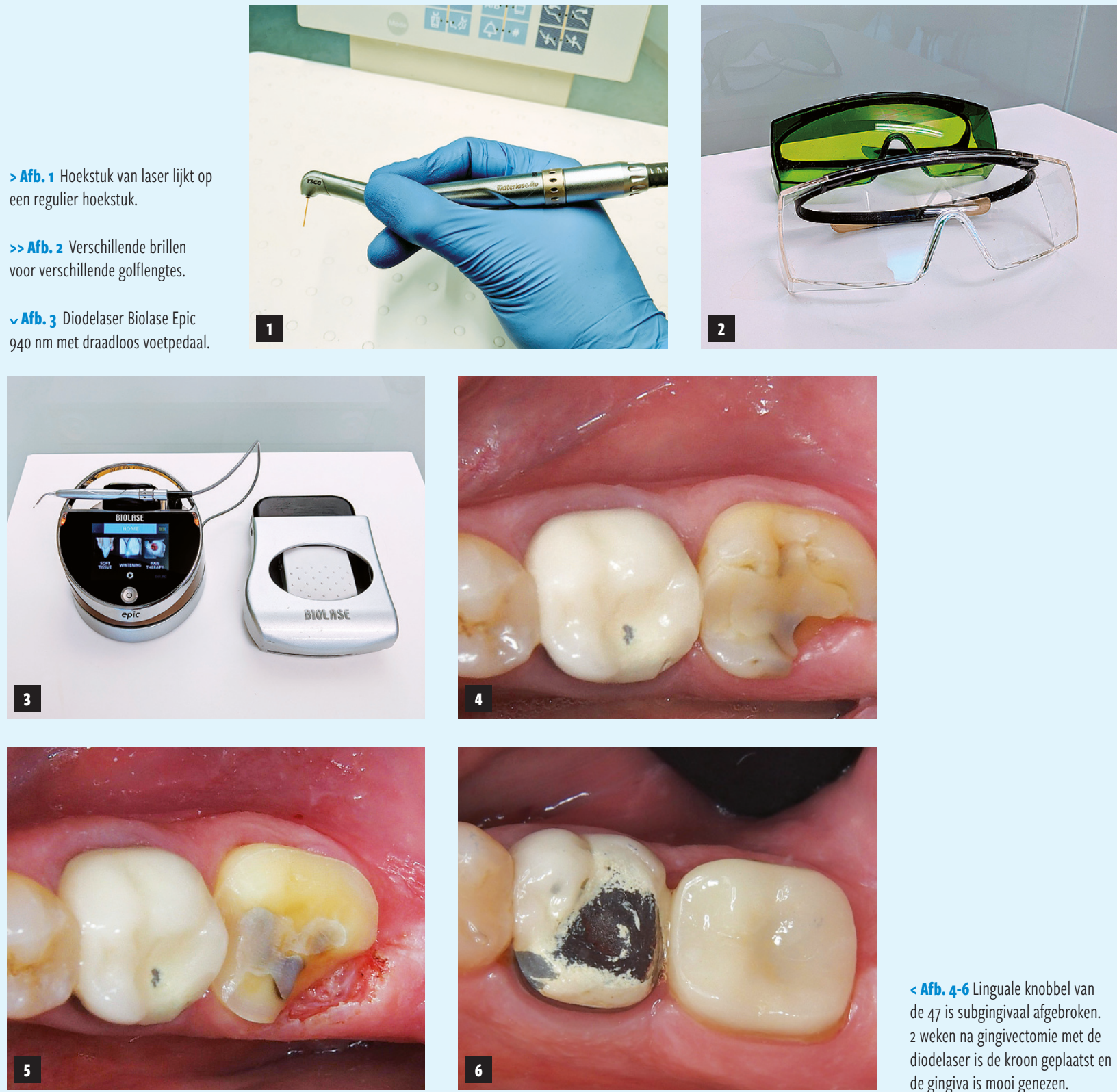

< Afb. 4-6 Linguale knobbel van de 47 is subgingivaal afgebroken. 2 weken na gingivectomie met de diodelaser is de kroon geplaatst en de gingiva is mooi genezen. 


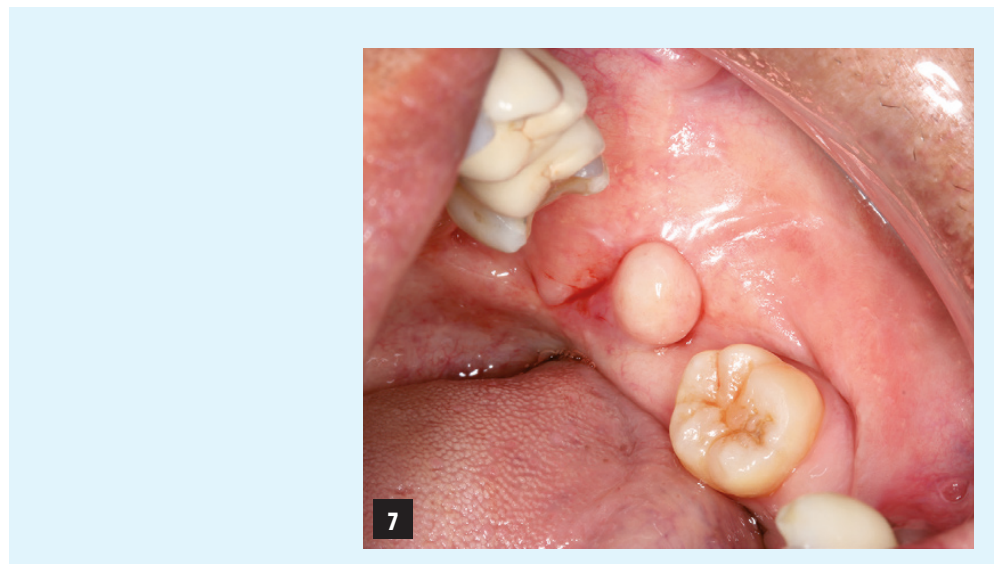

Afb. 7-9 Verwijdering van gesteeld fibroom. Lastige plek, maar met de diodelaser haal je hem weg zonder de wang of tong te beschadigen. Bloedingvrij resultaat.
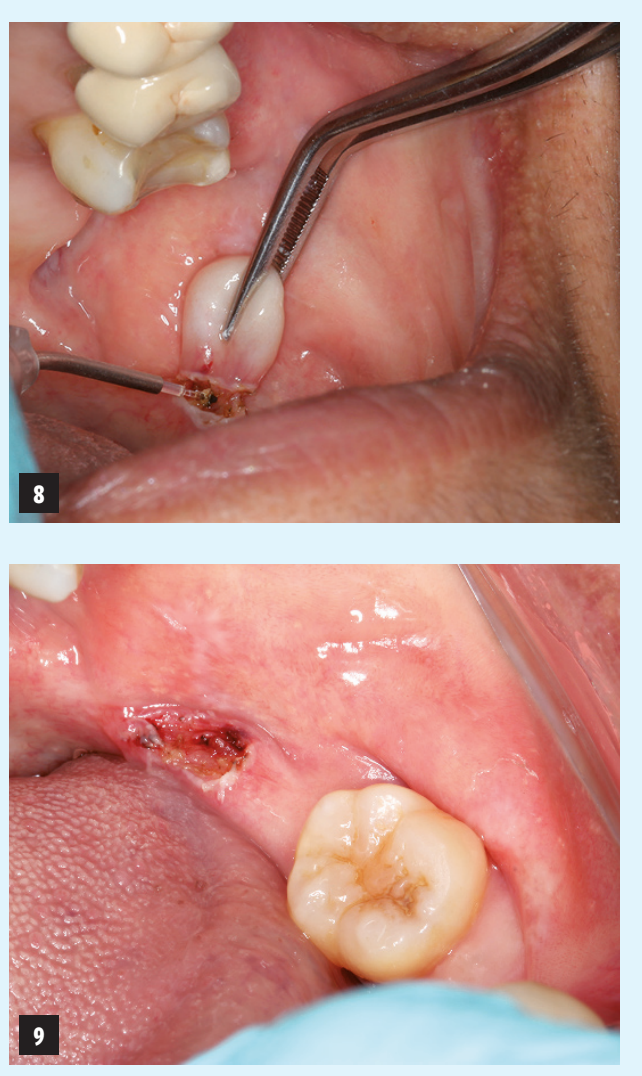

meer energie generen waardoor het celmetabolisme verhoogd wordt. Dit noemt men fotobiomodulatie of 'low level laser-therapie' (LLLT). Dit geldt alleen voor lasers met een golflengte van $450 \mathrm{~nm}$ tot $1000 \mathrm{~nm}$. De temperatuur van het weefsel komt hierbij niet boven de 37,5 ${ }^{\circ} \mathrm{C}$. In 1969 presenteerde Endre Mester, Hongaars wetenschapper, deze theorie. Hij bewees dat deze vorm van lichten energietoediening onder meer leidt tot meer energie, het verlichten van pijn en een snellere genezing en herstel. In vele landen (VS, Canada, Australië, Japan) is deze therapie volop geaccepteerd. In de dagelijkse praktijk kan je het bijvoorbeeld gebruiken bij aften om de pijn te verzachten en het herstel te versnellen (afbeelding 10). Andere toepassingen zijn bij drukplekken, alveolitis, myogene TMD (afbeelding 11) en bij trauma. De patiënten ervaren na behandeling minder pijn en snellere wondgenezing, zoals ook bij het verwijderen van een hematoom (afbeelding 12-13). In dit laatste geval gaat het laserlicht door de huid heen waardoor de onderliggende bloedvaatjes krimpen en het blauwe aspect verdwijnt.

Het tweede type laser is van een veel groter formaat en bevat onderdelen als een koel- en pompsysteem om de lasertip te koelen of de tip te beschermen tegen opspattend debris. Deze werken op basis van gas (bijv. CO2 of helium) of solid-state crystalen (bijv. Nd:YAG of Er:YAG). Naast een stekker voor stroom heeft hij ook een luchtaansluiting nodig. Er zit een uitneembaar waterreservoir in (afbeelding 14). Er zijn verschillende (disposable) tips te gebruiken voor de verschillende toepassingsgebieden (afbeelding 15).

\section{Minder pijn en een snellere wondgenezing}

De golflengte van deze lasers gaat van $1000 \mathrm{~nm}$ tot $10600 \mathrm{~nm}$. Het licht van deze laser wordt geabsorbeerd door water en hydroxyapatiet. Met deze lasers kan je zowel zachte als harde weefsels verwijderen. Het verwijderen van bot- en tandweefsel gebeurt door thermische ablatie: het watermolecuul in het weefsel absorbeert het laserlicht. Door de verhitting van de moleculen ontstaat er een explosie en gaat het weefsel kapot. Het oppervlak is hierdoor onregelmatig en niet zo glad als bij het gebruik van de boor of scalpel. Het grote voordeel bij verwijderen van glazuur, dentine en bot is dat er geen smeerlaag achterblijft. Door het gebruik van zeer korte lichtpulsen (microseconden of nanoseconden) kan je het weefsel oppervlakkig verwijderen zonder opwarming van de dieper gelegen delen. Ook hier geldt: minder schade leidt tot minder napijn en sneller genezing. Doordat 
het licht geabsorbeerd wordt door water is het snijden van zachte weefsel meer oppervlakkig en is het lastiger om hemostase te bereiken. Deze laser moet je niet zien als een vervanging van je boor. Het licht komt alleen uit de punt van de tip. Hierdoor 'boor' je alleen maar van bovenaf en niet met de zijkant, zoals je gewend bent. Een klasse II lukt nog wel, maar een kroonpreparatie zal zeer lastig worden. De volgende behandelingen gaan goed met dit tweede type laser: het verwijderen
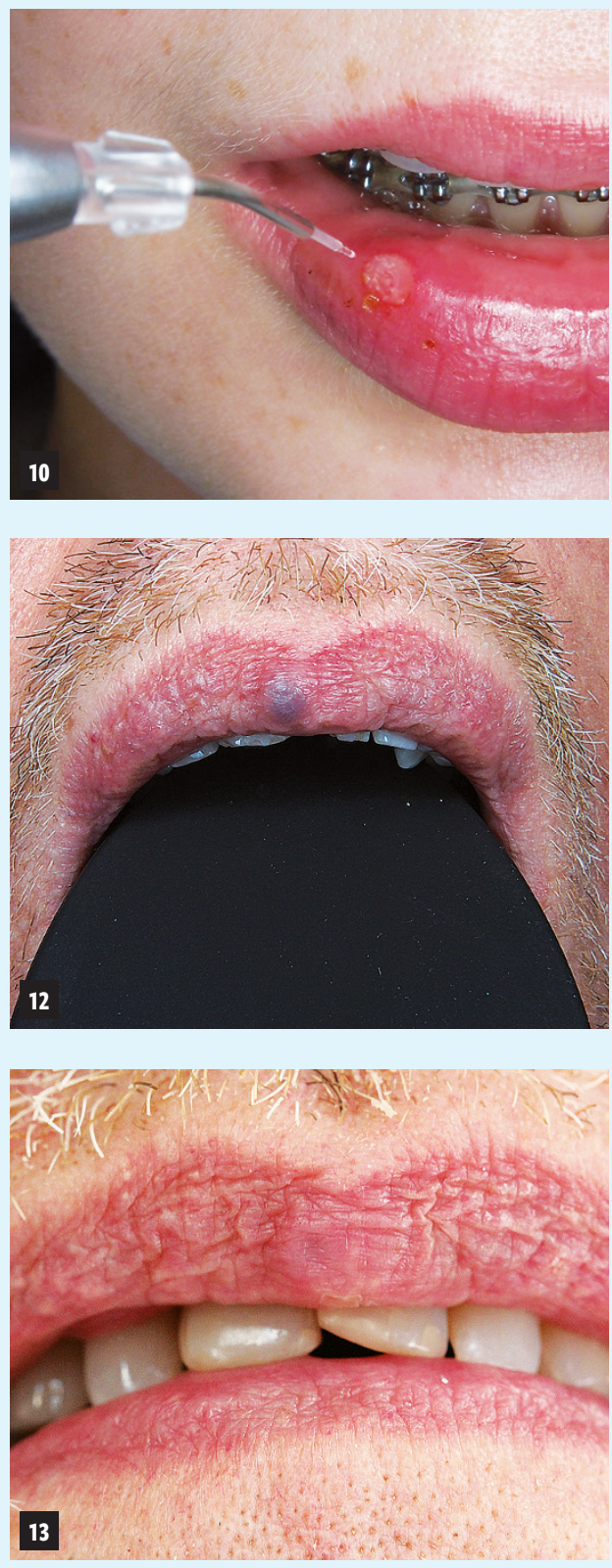

van lipbandjes om bijvoorbeeld orthodontische redenen (afbeelding 16-18). Je werkt mooi bloedingsvrij en het herstel is vrij van littekens.

Bij een 'closed flap' klinische kroonverlenging (afbeelding 19-22), een behandeling die ik regelmatig uitvoer, valt het mij op dat patiënten weinig klagen over napijn. Je hebt ook minder weefselschade dan bij een conventionele open-flapbehandeling. Een ander voordeel is dat je na de kroonverlenging meteen kan restaureren na verlagen van het

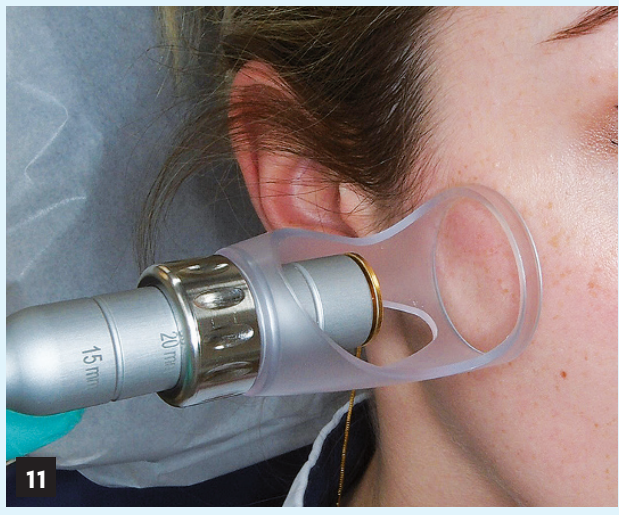

$>$ Afb. 10 Low level laser-therapie om pijn te verzachten en herstel te versnellen. Kleine lasertip voor behandelen afte op de lip.

> Afb. 11 Gebruik het grote handstuk voor bestrijding myogene TMD.

< Afb. 12-13 Begin en eindresultaat van laserbehandeling van hematoom.

> Afb. 14 De 'grote' laser: Biolase Waterlase MD ER;Cr:YSGG laser $(2780 \mathrm{~nm})$.

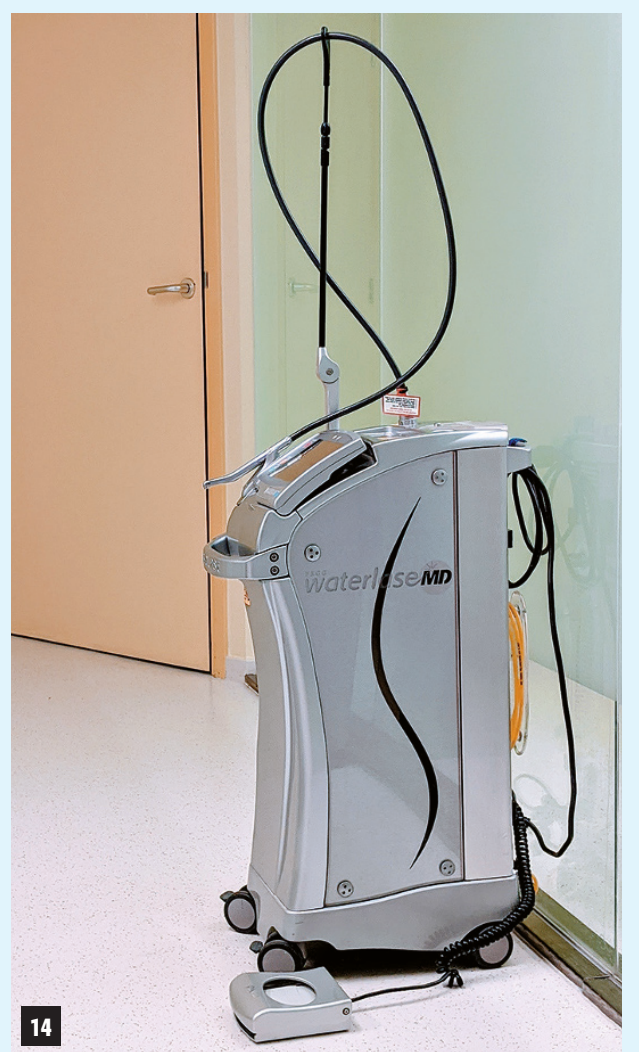


tp Casus De toepassing van laser in en rond de mond
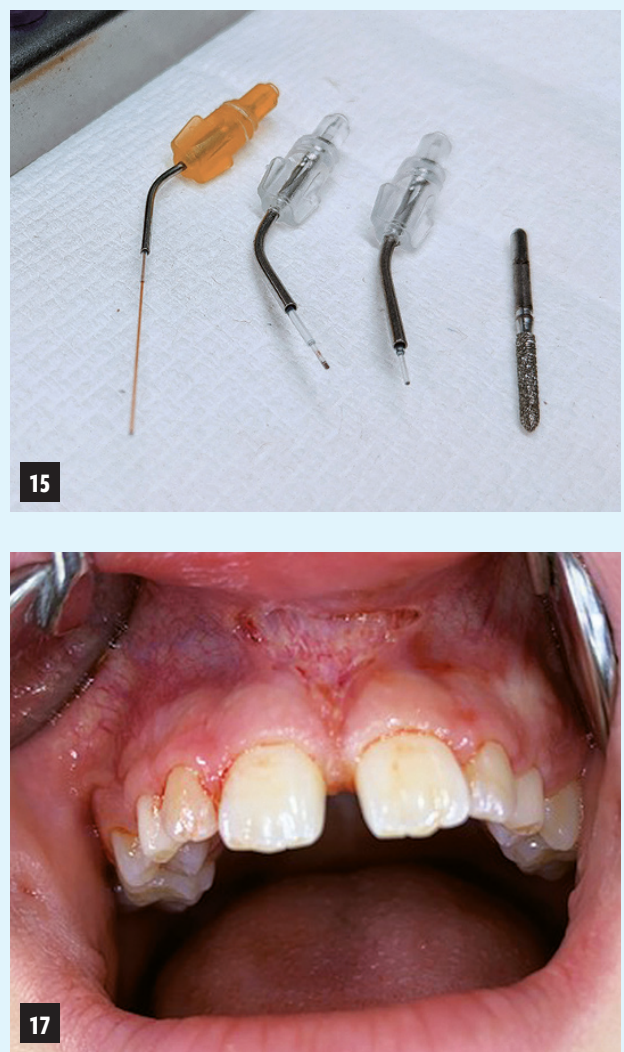

<Afb. 15 De verschillende (disposable) tips.

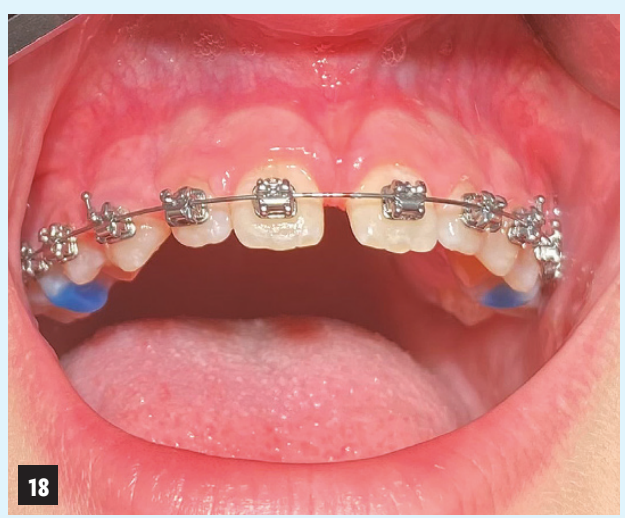

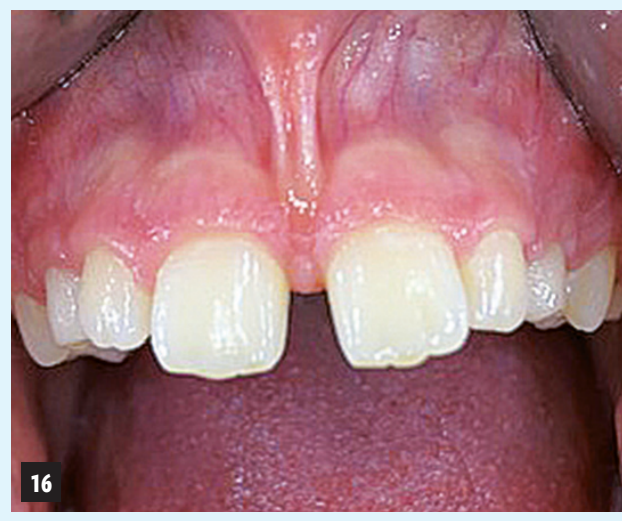

< Afb. 16-18 Verwijderen van het lipbandje voor, tijdens en na de behandeling.
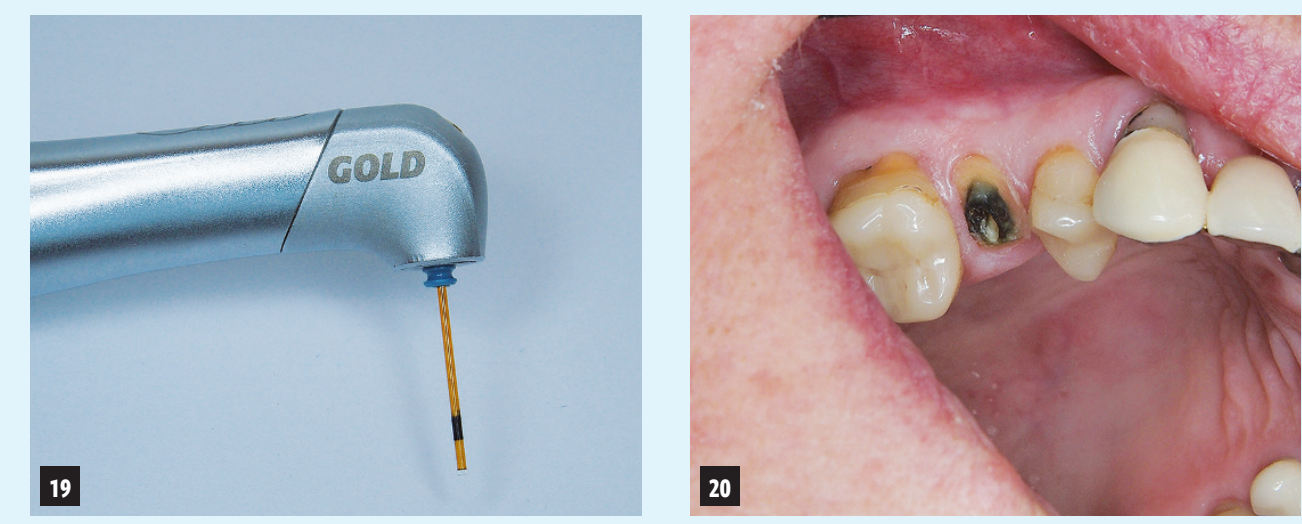

> Afb. 19-22 Na 8 jaar is de e.max-kroon op de 15 losgekomen. Duidelijk te weinig ferrule en het element is avitaal. Na endo en opbouw met deze tip een klinische kroonverlenging gedaan. Na 2 weken mooi genezen.

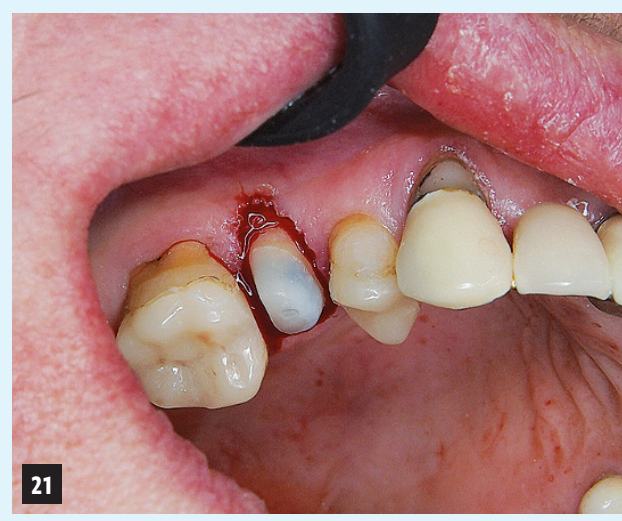


botniveau (afbeelding 23-24).

Voor parodontale behandelingen zijn er tips waarbij licht ook naar de zijkanten wordt uitgestraald: het uiteinde van de tip is in een punt geslepen. Er is zelfs een tip op de markt waarbij het licht in een hoek van $90^{\circ} \mathrm{kan}$ schijnen. Deze is speciaal voor het reinigen van implantaatoppervlakken. Belangrijk is om te weten dat metalen niet beschadigd worden, omdat deze geen water of andere chromoforen bevatten. Hierdoor kan je een implantaatoppervlak zonder probleem reinigen, maar een amalgaam uitboren lukt niet. Andere toepassing is het vrijleggen van een overgroeid abutment (afbeelding 25-26).

\section{DESINFECTIE}

Een ander groot voordeel van laserlicht is dat het bacteriën en schimmels kan doden. Dit kan met zowel de diodelaser als het tweede type laser (golflengte $1000 \mathrm{~nm}$ tot $10600 \mathrm{~nm}$ ) en op twee manieren. De directe methode waarbij het laserlicht geabsorbeerd wordt door de bacterie of schimmel. of de indirecte methode waarbij je gebruikmaakt van een vloeistof.

Bij de directe methode wordt het laserlicht van de diodelaser geabsorbeerd door het pigment in de bacterie. Hierdoor stijgt de temperatuur: bacteriën worden langzaam inactief en bij $60^{\circ} \mathrm{C}$ denatureren de proteïnen, wat weer leidt tot de dood van de bacterie. Diodelicht verhoogt daarnaast

\section{Na enige ervaring wil je niet meer anders}

de temperatuur in de pocket. Tandsteen droogt in en laat zich vervolgens makkelijker verwijderen. Zowel het tandoppervlak als het pocketepitheel wordt zo belicht en gedesinfecteerd. Bij de lasers van het tweede type wordt het licht door het water in de bacterie geabsorbeerd. Het watermolecuul explodeert en de bacterie sterft. Naast bacteriereductie verwijder je ook granulatieweefsel en tandsteen als dat aanwezig is.
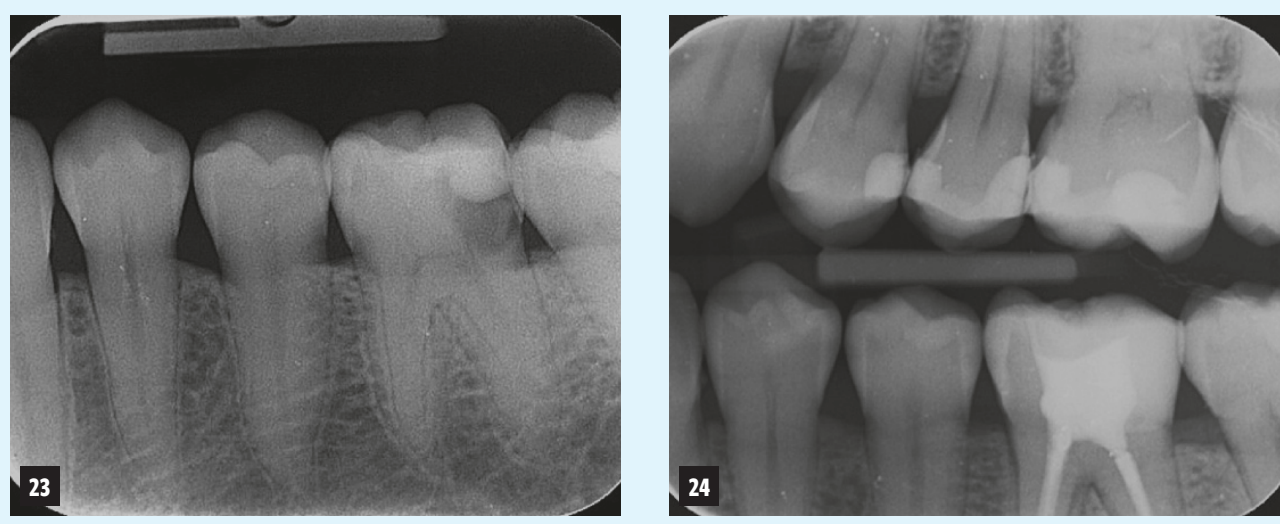

< Afb. 23-24 Hier is duidelijk het verschil in bothoogte te zien tussen de mesiale en distale zijde na kroonverlenging.
>Afb. 25-26 Met de ER;Cr:YSGG laser een dalbo-abutment vrijgelegd. Geen zorgen om eventuele beschadiging van het metaal (want is ongevoelig voor laserlicht).
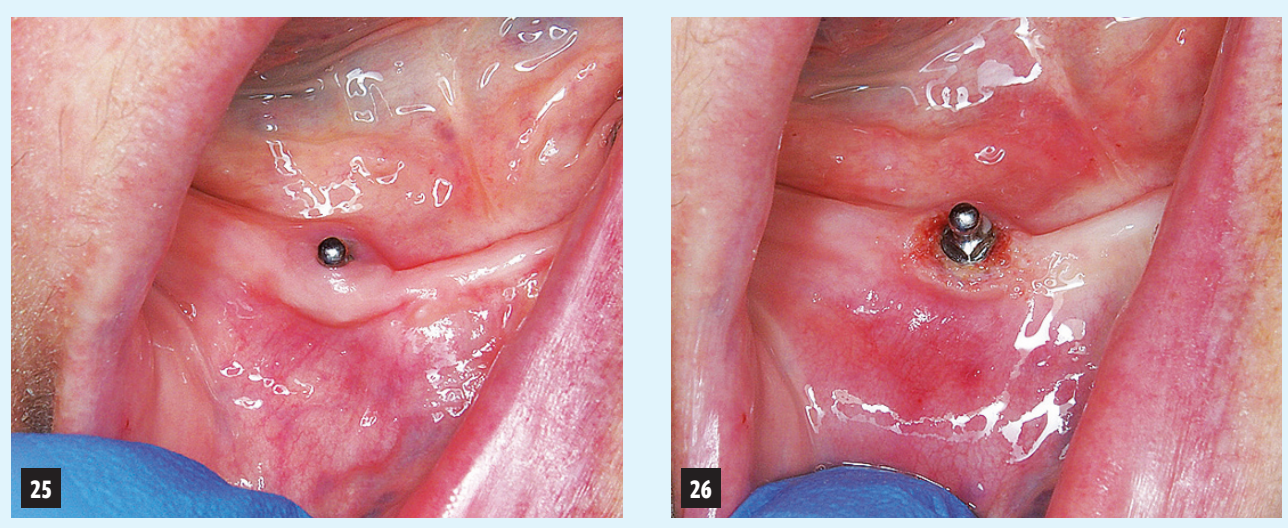

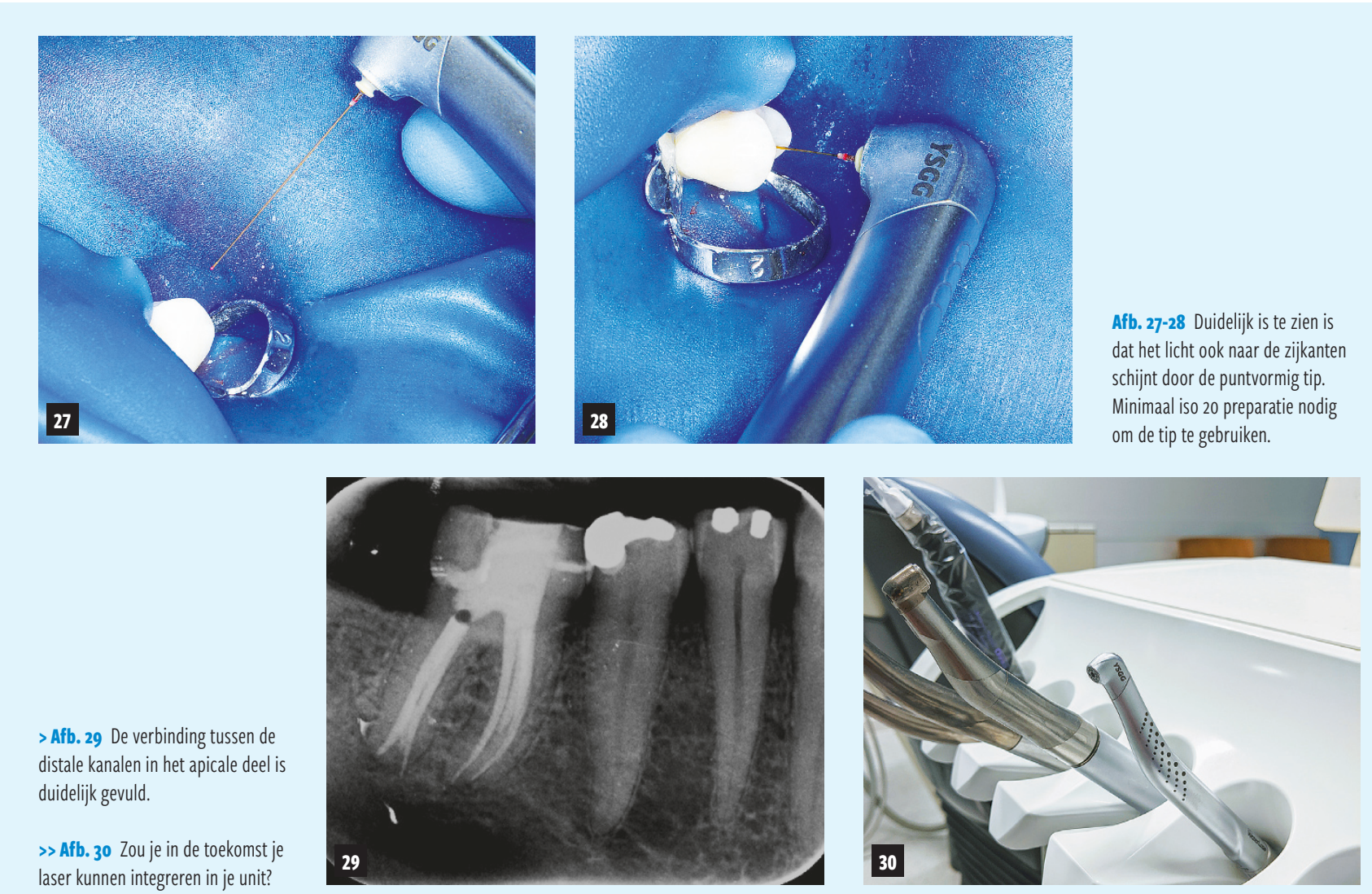

Bij endodontische behandelingen (afbeelding 2728) dringt het licht diep in de wortel en in combinatie met natriumhypochloride zie je in sommige onderzoeken een grotere reductie van bacteriën dan bij het gebruik van natriumhypochloride alleen. Er zijn zelfs tandartsen en endodontologen die geen natriumperoxide meer gebruiken en volledig vertrouwen op de laserdesinfectie.

Bij de indirecte methode gebruik je het laserlicht in combinatie met een vloeistof. In de pocket kan je 3\% waterstofperoxide aanbrengen en 30 seconden activeren met diodelicht. Je ziet dan de waterstof bruisen: er komen zuurstofradicalen vrij die schadelijk zijn voor de bacteriën en schimmels. Waterstofperoxide is door covid-19 inmiddels in alle tandartspraktijken te vinden. De onderzoeken op dit gebied zien er veelbelovend uit. Andere vloeistoffen zijn bijvoorbeeld methyleenblauw of indocyaninegroen.

Bij de lasers waarbij het licht geabsorbeerd wordt door water (golflengte $1000 \mathrm{~nm}$ en hoger) zie je dat er cavitatie optreedt bij het activeren van wa- ter, EDTA of natriumhypochloriet. Je pompt als het ware de vloeistof door het wortelkanaalsysteem of pocket. Het voordeel van het gebruik van een vloeistof is dat je niet alle te behandelen weefseloppervlakken hoeft te belichten. Dit laatste zie je goed bij een endo waarbij na het 1 minuut activeren van de EDTA, spoelen met water (gewoon gedemineraliseerd water van de laser) en 1 minuut $\mathrm{NaOH} 6 \%$ activatie duidelijk een verbinding tussen de distale kanalen het apicale deel te zien is (afbeelding 29).

Een laser lijkt op een Zwitsers zakmes. Je kan er van alles mee. De ene tandarts vindt het een nuttige toevoeging, de andere vindt het overdreven. Mijn ervaring is dat als je eenmaal een laser hebt aangeschaft en gebruikt, je niet anders meer wil. Een kroonrand vrijleggen is kinderspel, bloedend tandvlees verstoort je behandeling niet meer en die klinische kroonverlenging kan je zelf uitvoeren. Misschien zit de laser in de toekomst wel geïntegreerd in de unit! (Afbeelding 30) 